\title{
Interaction Orientation, Innovative Method and Corporate Performance
}

\author{
Xiuming Ma \\ Correspondence: Xiuming Ma, Chinese Graduate School, Panyapiwat Institute of Management, Nonthaburi 11120, \\ Thailand. E-mail: bbwmxm@163.com
}

Received: December 28, 2019 Accepted: January 18, 2020 Online Published: January 20, 2020

doi:10.5539/jmr.v12n1p62

URL: https://doi.org/10.5539/jmr.v12n1p62

\begin{abstract}
With the rapid rise of Internet information technology, communication between enterprises and customers has gradually become a normal. The study found that interaction orientation helps drive innovation in companies. Interactive orientation plays a significant positive role in improving corporate performance. Corporate innovation helps improve corporate performance. The effect of interaction orientation on customer-based profitability is accomplished by relying on corporate innovation, and it plays a part of the intermediary role.
\end{abstract}

Keywords: interactive orientation, innovative approach, corporate performance

\section{Description of the Problem}

Ramani and Kumar (2008) point out that companies adopting an interactive orientation must be able to communicate effectively with individual customers and use this interaction to continuously obtain information. There are multiple theories in the analysis that can provide references, such as market orientation, customer participation, and innovation theory. Such theories provide a theoretical basis for the development of interaction-oriented theories. The four dimensions of the interaction-oriented theory largely reflect and integrate the core ideas of the above four theories. In addition, the development and research ideas of market-oriented theory provide important inspiration for the continuous improvement of interactive-oriented theory.In order to fill the gaps in the existing research and dispel the concerns and doubts about interaction orientation from various circles, with the results of many related literatures as the basis, this paper, based on the guidance on the corporate interaction, analyzes its effects on innovation methods and performance of enterprise. It also analyzes the mechanism of its effect on corporate performance (mainly the customer-based profit performance). Based on such effect, the paper deeply analyzes the range of application of interaction orientation, which acts as a basis to determine the theoretical framework in which interaction orientation, innovation method (incremental innovation and radical innovation) and corporate performance (customer-based relationship performance and customer-based profit performance) and relevant hypotheses are related to each other. Based on some enterprises in Guangdong and Shandong provinces, an empirical test of the above hypotheses is carried out, and then the theory is expanded to make enterprises to operate based on evidence.

In the current literature, research results on interaction orientation and company innovation are rare. There is still a lack of more in-depth analysis of the impact of corporate performance. The detailed scope of application requires subsequent continuous research and discussion.

\section{Literature Review and Theoretical Hypothesis}

\subsection{The Impact of Interactive Orientation on Enterprise Innovation}

Interaction-oriented is a strategic concept that emphasizes the concept of customers. Interaction-oriented advocates that companies can interact with customers in a friendly and continuous manner during operations and development, to facilitate enterprises to accurately and comprehensively understand customer needs, and to adjust and optimize products based on customer needs. Therefore, interactive orientation can promote corporate innovation (Wei Haiying et al., 2012). Interactive orientation can not only promote the further improvement of corporate performance, but also accelerate the pace of corporate innovation to a certain extent (Chen Haowen, Li Yuan and Liu Heng, 2011).

Based on the above literature, the corresponding research hypotheses are proposed:

H1: Interactive orientation can have a significant positive impact on progressive corporate innovation.

\subsection{The Impact of Interaction Orientation on Corporate Performance}

This study proposes that interaction orientation can improve corporate performance. It is specifically explained as follows: First, good development and management of customers can enable the company to achieve more adequate 
customer value under certain conditions, thereby improving its own profit margins. . Therefore, customer value management can guarantee the profit performance of the company's customers. Second, interactive orientation allows companies to better identify and maintain valuable customers. Based on the above analysis, the following hypothetical content is created here.

H2: Interaction orientation has a positive effect on corporate performance, which means that the company's level of interaction orientation improves. At this time, corporate performance is more ideal.

\subsection{The Impact of Corporate Innovation on Corporate Performance}

Innovation is a reliable guarantee for enterprises to maintain their competitive advantages, improve performance levels, and achieve sustainable development. Among them. Enterprise innovation is in line with the actual requirements of current customers. Because enterprise innovation focuses on the optimization and improvement of current products and services, it can more ideally meet and maintain existing customers at the same time, and find and develop products or services that meet potential needs. Let the company get more high-quality new customers. At the same time, development and design activities based on new knowledge can improve the level of products or services, so it can largely avoid the impact of impact from competitors, so it can improve corporate performance. Based on the above analysis, the following hypothetical content is created here.

H3: Corporate innovation has a positive effect on corporate performance, that is, the company's degree of innovation is deeper, and corporate performance is more ideal at this time.

\subsection{Intermediary Role of Corporate Innovation}

The effect of interaction orientation on company performance is accomplished through corporate innovation. Here are specific explanations and analyses: First, interaction orientation can accelerate corporate innovation. Secondly, interaction orientation can promote the improvement of corporate performance. Finally, the role of interaction-oriented to corporate performance is accomplished through corporate innovation, in other words, the latter acts as an intermediary bridge. In addition to interactive guidance, it can use the impact on the company's innovation to meet the explicit needs of customers, so as to obtain more ideal performance; at the same time, it can use the innovation that acts on the company to meet the hidden needs of customers, thereby forming more Desirable performance. Based on the above analysis, the hypothetical content created here is the following two points:

H4: Interactive behaviors on corporate performance are accomplished through corporate innovation.

\section{Research Methods}

\subsection{Scale Design}

In this study, scales designed by Ramani et al. were used to measure interaction orientation, innovative methods, and company performance. The measurement was performed using a Likert 7-point scale.

\subsection{Data Collection}

This study selected companies in Guangdong and Shandong provinces to conduct research. A convenient sampling method was adopted, and a total of 300 enterprises in Guangdong Province and Shandong Province were selected for research. The effective recovery rate was $74.6 \%$.

\subsection{Data Analysis Method}

The data analysis of this study mainly includes three parts: descriptive statistical research, validity and reliability research, and verification of hypotheses. The descriptive statistical analysis focuses on the mean, standard deviation, and frequency distribution. In order to further determine the accuracy and stability of the measurement results, research on reliability and validity is carried out around the scale to ensure that the obtained research conclusions are positive and effective. The method of multiple regression analysis was used for empirical test. 


\section{Data Analysis and Model Testing}

\subsection{Test on Reliability and Validity of the Scales}

Table 4.1 and 4.2 and 4.3 display, tshe scale has good reliability and validity.

Table 4.1. Reliability analysis of the scales

\begin{tabular}{cc}
\hline Variable & Cronbach's $\alpha$ \\
\hline Interaction orientation & 0.820 \\
Incremental innovation & 0.660 \\
Radical innovation & 0.642 \\
Customer-based profit & 0.686 \\
performance & \\
Customer-based relationship & 0.614 \\
performance & \\
\hline
\end{tabular}

Table 4.2. The values of AVE and CR in each scale

\begin{tabular}{ccc}
\hline Scale & AVE & CR \\
\hline Interaction orientation & 0.4985 & 0.9132 \\
Incremental innovation & 0.5041 & 0.8080 \\
Radical innovation & 0.4584 & 0.7603 \\
Customer-based profit & 0.4676 & 0.713 \\
performance & & \\
Customer-based & 0.4847 & 0.7372 \\
relationship performance & & \\
\hline
\end{tabular}

Table 4.3. Analysis of discriminant validity in each scale

\begin{tabular}{|c|c|c|c|c|c|c|c|}
\hline & $\begin{array}{l}\text { Averag } \\
\text { e value }\end{array}$ & $\begin{array}{l}\text { Standard } \\
\text { deviation }\end{array}$ & $\begin{array}{l}\text { Interaction } \\
\text { orientation }\end{array}$ & $\begin{array}{l}\text { Incremental } \\
\text { innovation }\end{array}$ & $\begin{array}{l}\text { Radical } \\
\text { innovation }\end{array}$ & $\begin{array}{l}\text { Profit } \\
\text { performance }\end{array}$ & $\begin{array}{l}\text { Relationship } \\
\text { performance }\end{array}$ \\
\hline $\begin{array}{l}\text { Interaction } \\
\text { orientation }\end{array}$ & 4.76 & 0.94 & 0.7068 & & & & \\
\hline $\begin{array}{l}\text { Incremental } \\
\text { innovation }\end{array}$ & 5.61 & 0.80 & 0.5631 & 0.7107 & & & \\
\hline $\begin{array}{l}\text { Radical } \\
\text { innovation }\end{array}$ & 4.21 & 1.08 & 0.4207 & 0.4437 & 0.6767 & & \\
\hline $\begin{array}{l}\text { Profit } \\
\text { performance }\end{array}$ & 4.35 & 1.00 & 0.4440 & 0.3555 & 0.4780 & 0.6835 & \\
\hline $\begin{array}{l}\text { Relationship } \\
\text { performance }\end{array}$ & 4.04 & 1.07 & 0.4502 & 0.3208 & 0.3650 & 0.4416 & 0.6860 \\
\hline
\end{tabular}

\subsection{Hypotheses Verification}

4.2.1 The Impact of Interactive Orientation on Enterprise Innovation

Table 4.4. Regression Analysis of the Impact of Interactive Orientation on Enterprise Innovation

\begin{tabular}{|c|c|c|c|c|c|}
\hline \multicolumn{2}{|c|}{ Variables } & \multirow{2}{*}{$\begin{array}{r}\text { Model (I) } \\
\text { The value of } \beta\end{array}$} & \multicolumn{3}{|c|}{ Model (II) } \\
\hline & & & The value of $\mathrm{T}$ & The value of $\beta$ & The value of $\mathrm{T}$ \\
\hline $\begin{array}{l}\text { Control } \\
\text { variables }\end{array}$ & $\begin{array}{l}\text { Enterprise } \\
\text { scale }\end{array}$ & 0.036 & 1.206 & 0.042 & 1.724 \\
\hline $\begin{array}{l}\text { Independen } \\
\text { t variables }\end{array}$ & $\begin{array}{l}\text { Interaction } \\
\text { orientation }\end{array}$ & - & - & 0.542 & $10.150 * * *$ \\
\hline & R2 & & 0.006 & & 0.323 \\
\hline & Adjusted R2 & & 0.003 & & 0.307 \\
\hline & $\Delta \mathrm{R} 2$ & & - & & 0.306 \\
\hline
\end{tabular}

Note: $* * * \mathrm{p}<0.001, * * \mathrm{p}<0.01 * \mathrm{p}<0.05$ 
The data in the table is analyzed in Table 4.4, which shows that for model (I), the value of $\beta 1$ is equal to 0.036 , and it is not significant, that is, the size of the company does not significantly affect the innovation of the company. For model (II), the value of $\beta 2$ is equal to 0.542 , and its p-value is less than 0.001 , indicating that if the size of the company is effectively controlled, progressive innovation will be significantly affected by interaction orientation. It can be seen that the positive impact of interactive orientation on corporate innovation is significant. In addition, in model (II), the value of R2 is equal to 0.323 , which means that the specific explanatory power of progressive innovation being interactively oriented is equal to $32.3 \%$. In other words, the latter is a factor that has an important influence on the former. So, H1 holds.

4.2.2 The Impact of Interaction Orientation on Corporate Performance

Table 4.5. Regression Analysis of Interaction Orientation on Corporate Relationship Performance

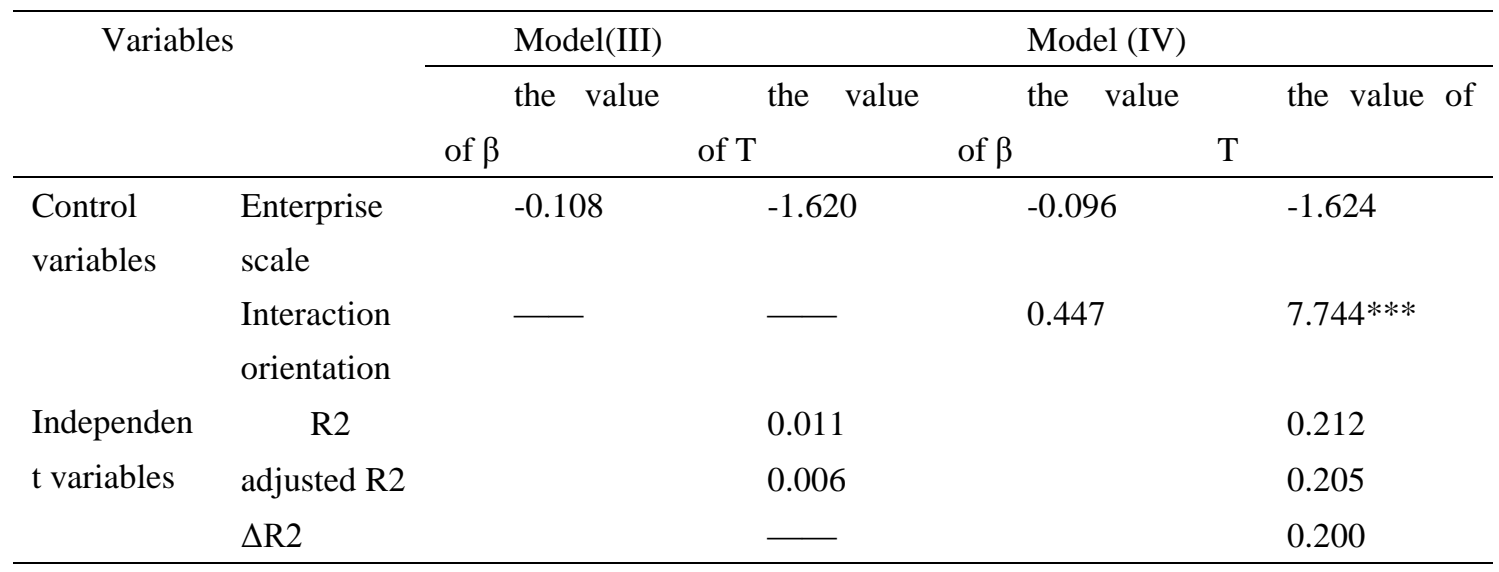

Note: $* * * \mathrm{p}<0.001, * * \mathrm{p}<0.01 * \mathrm{p}<0.05$

Based on the analysis of the data in the above table, it is found that in model (III), the value of $\beta 1$ (the size of the standardized regression coefficient) is equal to -0.180 , which is not significant (the $\mathrm{p}$ value is 0.105 , and the $t$ value Is -1.620). In the model (IV), the value of $\beta 1$ is equal to -0.096 , which is not significant (its $p$ value is 0.105 and its $t$ value is -1.624). From the above results, it can be seen that the relationship performance based on the customer is not significantly affected by the control variable (here, the size).

For the model (IV), it can be seen that the value of $\beta 2$ is equal to 0.447 , which is significantly different from 0 (its $p$ value is less than 0.00). It means that interaction-oriented variables have a significant positive impact on corporate performance. In this model, the obtained R2 value is 0.212 , which means that the ability of the company to explain the interaction-oriented factors is equal to $21.2 \%$. The above work confirms that interaction-oriented is the key influencing factor for customer-based relationship performance This one. So, $\mathrm{H} 2$ holds.

4.2.3 The Impact of Corporate Innovation on Corporate Performance

Table 4.6. Regression Analysis of Enterprise Innovation on Enterprise Performance

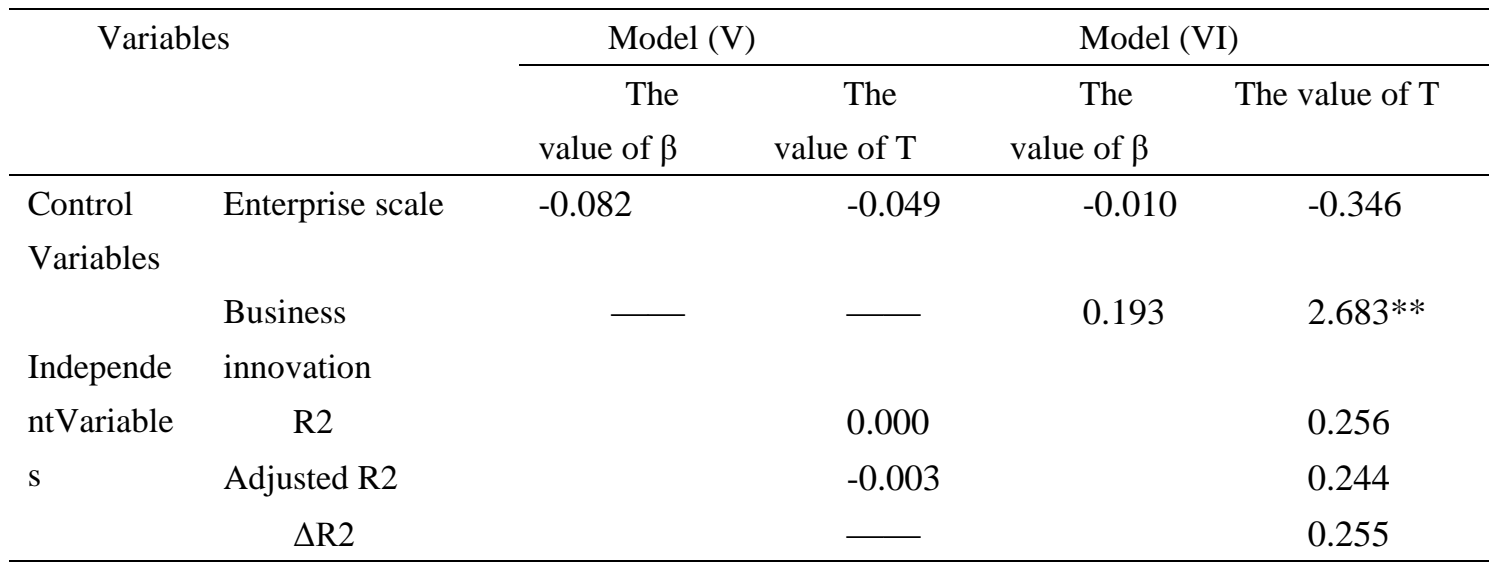

Note: $* * * \mathrm{p}<0.001, * * \mathrm{p}<0.01 * \mathrm{p}<0.05$

Analyzing the results of the data in Table 4.6 above, we can find that in the model (V), its $\beta 1$ value is equal to -0.082 and is not significant (its p-value is 0.960 , and its t-value is -0.049 ). In the model (VI), its $\beta 1$ value is equal to -0.010 , and it is not significant (its $\mathrm{p}$ value is 0.730 , and its $t$ value is 0.346 ). It can be seen that based on the performance level 
of the company, it is not subject to control variables (that is, the company Size).

In addition, in the model (VI), it can be seen that the value of $\beta 2$ is equal to 0.194 , which is significantly not equal to 0 (its $p$ value is less than 0.01 ); and the value of $\beta 3$ is 0.373 , which is significantly not equal to 0 (its $p$ value is less than 0.01). It means that corporate innovation has a positive impact on corporate performance levels. In this model, the R2 value is 0.256 , which means that the size of the company's ability to be interpreted based on the enterprise's innovation level is equal to $25.6 \%$. The above work confirms that for the enterprise's performance, the enterprise's innovation is a key influencing factor.

Therefore, $\mathrm{H} 3$ is valid.

4.2.4 Intermediary Role of Corporate Innovation

Table 4.7. Intermediary role of enterprise innovation

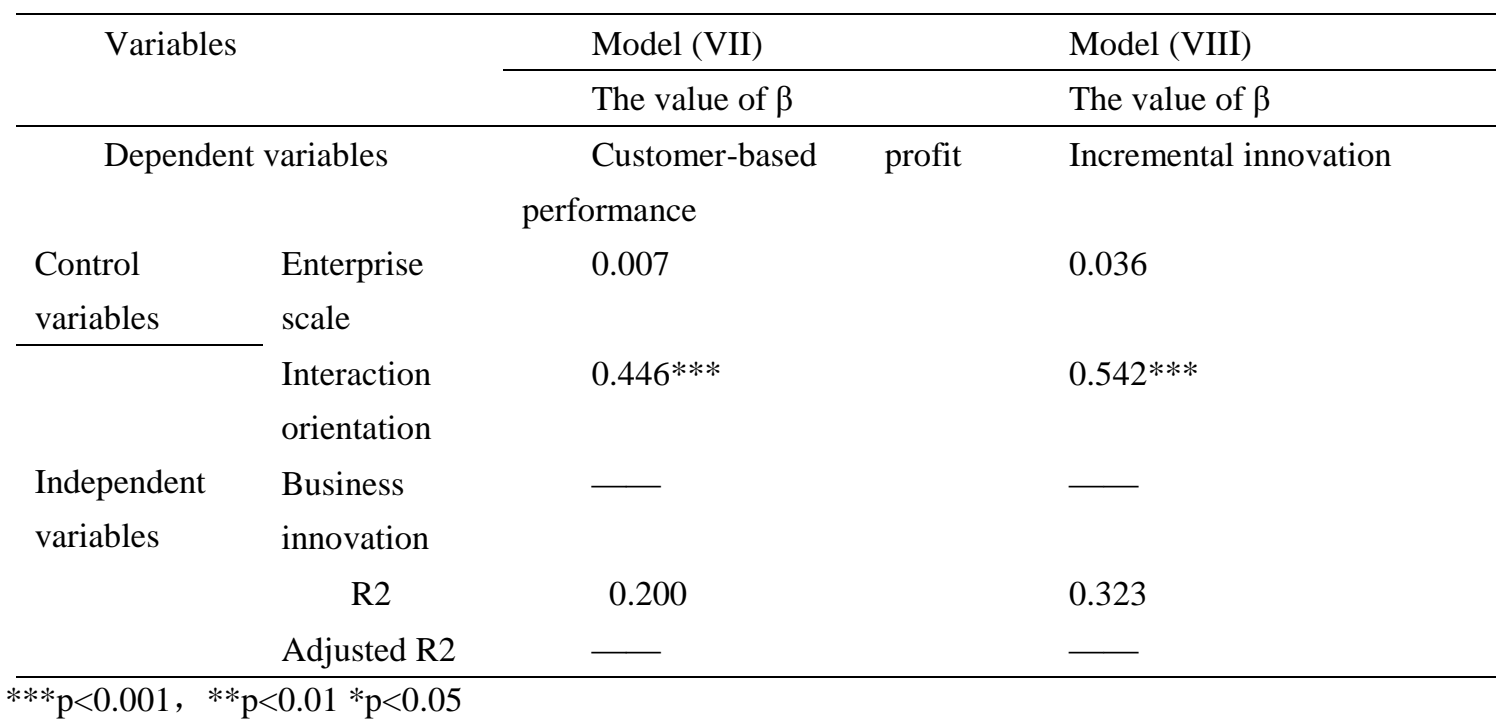

Note: $* * * \mathrm{p}<0.001, \quad * * \mathrm{p}<0.01 * \mathrm{p}<0.05$

In the table above, the first column of data is mainly for the test of the first step. According to the relevant data, if the size of the company is controlled, the standardized regression coefficient of the interaction orientation is 0.446 , which is significantly not equal to 0 (its $\mathrm{p}$ value is less than 0.001 ), which means that the interaction orientation will produce a profit performance level based on the customer. It has positive effects and is significant. From this we can see that the first step of this work is valid.

In the table above, the second column of data is mainly for the test of the second step. According to relevant data, if the size of the enterprise is controlled, the standardized regression coefficient of the interaction orientation is 0.542 , which is significantly not equal to 0 (its $\mathrm{p}$ value is less than 0.001 ), which means that the interaction orientation will have a positive impact on progressive innovation., And is significant, it can be seen that the second step of this work is valid.

According to the above research results, in the process of corporate performance affected by interactive orientation, corporate innovation played a certain mediating role, $\mathrm{H} 4$ was established.

\section{Research Conclusions and Implications}

In this study, companies from Guangdong and Shandong provinces were taken as the corresponding samples, and the above hypothesis content was demonstrated and analyzed concretely. According to the above analysis, we have found some conclusions that can prove the subject research. Here we summarize the conclusions of the research as follows: First, interaction orientation can speed up enterprise innovation. In addition, interactive orientation can improve business performance. Second, corporate innovation can improve corporate performance to a certain extent. Finally, interactive orientation can improve corporate performance through corporate innovation. According to the conclusions obtained above, the rationality and scientificity of the relationship marketing theory have been further demonstrated, that is, the use of creating a stable and long-term relationship with customers can enhance the company's profitability and achieve stable development in the long run. Obtain a reasonable positioning of itself in the competitive market. 


\section{References}

Amoako-Gyampah, K., \& Acquaah, M. (2008). Manufacturing strategy, competitive strategy and firm performance: An empirical study in a developing economy environment. International journal of production economics, 111(2), 575-592. https://doi.org/10.1016/j.ijpe.2007.02.030

Anderson, E. W., Fornell, C., \& Mazvancheryl, S. K. (2004). Customer satisfaction and shareholder value. Journal of marketing, 68(4), 172-185. https://doi.org/10.1509/jmkg.68.4.172.42723

Anderson, J. C., \& Gerbing, D. W. (1988). Structural equation modeling in practice: A review and recommended two-step approach. Psychological bulletin, 103(3), 411. https://doi.org/10.1037/0033-2909.103.3.411

Auh, S., \& Menguc, B. (2005). Balancing exploration and exploitation: The moderating role of competitive intensity. Journal of business research, 58(12), 1652-1661. https://doi.org/10.1016/j.jbusres.2004.11.007

Bagozzi, R. P., \& Yi, Y. (1988). On the evaluation of structural equation models. Journal of the academy of marketing science, 16(1), 74-94. https://doi.org/10.1007/BF02723327

Bolton, R. N. (2004). Invited commentaries on "Evolving to a new dominant logic for marketing". Journal of Marketing, 68(1), 18-27. https://doi.org/10.1509/jmkg.68.1.18.24035

Farjoun, M. (2010). Beyond dualism: Stability and change as a duality. Academy of management review, 35(2), $202-225$. https://doi.org/10.5465/amr.35.2.zok202

Fornell, C., \& Larcker, D. F. (1981). Evaluating structural equation models with unobservable variables and measurement error. Journal of marketing research, 18(1), 39-50. https://doi.org/10.1177/002224378101800104

Fortuin, L. (1988). Performance indicators-why, where and how?. European journal of operational research, 34(1), 1-9. https://doi.org/10.1016/0377-2217(88)90449-3

Frederick, N. (2003). Why CRM doesn't Work: How to Win by letting Customers Manage the Relationship.

Hoekstra, J. C., Leeflang, P. S., \& Wittink, D. R. (1999). The customer concept: the basis for a new marketing paradigm. Journal of market-focused management, 4(1), 43-76. https://doi.org/10.1023/A:1009856028285

Hogan, J. E., Lemon, K. N., \& Libai, B. (2003). What is the true value of a lost customer?. Journal of Service Research, 5(3), 196-208. https://doi.org/10.1177/1094670502238915

Jansen, J. J., Van den Bosch, F. A., \& Volberda, H. W. (2005). Exploratory innovation, exploitative innovation, and ambidexterity: The impact of environmental and organizational antecedents. Schmalenbach Business Review, 57(4), 351-363. https://link.springer.com/article/10.1007/BF03396721

Jaworski, B. J., \& Kohli, A. K. (1993). Market orientation: antecedents and consequences. Journal of marketing, 57(3), 53-70. https://doi.org/10.1177/002224299305700304

Kohli, A. K., \& Jaworski, B. J. (1990). Market orientation: the construct, research propositions, and managerial implications. Journal of marketing, 54(2), 1-18. https://doi.org/10.1177/002224299005400201

Kohli, A. K., Jaworski, B. J., \& Kumar, A. (1993). MARKOR: a measure of market orientation. Journal of Marketing research, 30(4), 467-477. https://doi.org/10.1177/002224379303000406

Matsuno, K., \& Mentzer, J. T. (2000). The effects of strategy type on the market orientation-performance relationship. Journal of marketing, 64(4), 1-16. https://doi.org/10.1509/jmkg.64.4.1.18078

Olson, E. M., Slater, S. F., \& Hult, G. T. M. (2005). The performance implications of fit among business strategy, marketing organization structure, and strategic behavior. Journal of marketing, 69(3), 49-65. https://doi.org/10.1509/jmkg.69.3.49.66362

Prahalad, C. K., \& Ramaswamy, V. (2004). The future of competition: Co-creating unique value with customers. Harvard Business Press. https://doi.org/10.1108/10878570410699249

Rayport, J. F., Jaworski, B. J., \& Kyung, E. J. (2005). Best face forward: Improving companies' service interfaces with customers. Journal of Interactive Marketing, 19(4), 67-80. https://doi.org/10.1002/dir.20050

Reinartz, W. J., \& Kumar, V. (2003). The impact of customer relationship characteristics on profitable lifetime duration. Journal of marketing, 67(1), 77-99. https://doi.org/10.1509/jmkg.67.1.77.18589

Rust, R. T., Moorman, C., \& Bhalla, G. (2010). Rethinking marketing. Harvard business review, 88(1/2), 94-101.

Sheth, J. N., Sisodia, R. S., \& Sharma, A. (2000). The antecedents and consequences of customer-centric marketing. Journal of the Academy of marketing Science, 28(1), 55-66. https://doi.org/10.1177/0092070300281006 
Yadav, M. S., \& Varadarajan, P. R. (2005). Understanding product migration to the electronic marketplace: A conceptual framework. Journal of Retailing, 81(2), 125-140. https://doi.org/10.1016/j.jretai.2005.03.006

Zhou, K. Z., \& Poppo, L. (2010). Exchange hazards, relational reliability, and contracts in China: The contingent role of legal enforceability. Journal of International Business Studies, 41(5), 861-881. https://doi.org/10.1057/jibs.2010.7

\section{Copyrights}

Copyright for this article is retained by the author(s), with first publication rights granted to the journal.

This is an open-access article distributed under the terms and conditions of the Creative Commons Attribution license (http://creativecommons.org/licenses/by/4.0/). 